\title{
Fostering the Attitude of Nationalism Through Hizbul Wathan as the Extracurricular to Build Students Character
}

\author{
Amrina Rosyada \\ Student of Citizenship Education \\ Universitas Pendidikan Indonesia \\ Bandung, Indonesia \\ amrinaarosyadaa@gmail.com
}

\author{
Endang Danial AR \\ Lecturer of Citizenship Education \\ Universitas Pendidikan Indonesia \\ Bandung, Indonesia
}

\begin{abstract}
This research aims to determine attitude of nationalism coaching students through extracurricular activities hizbul wathan to build the character of students in SMA Muhammadiyah 1 Palembang and various problems faced by schools in the process of fostering. As the research method, this study used the case study with a sample of 15 respondents. Then, to collect the data, this study used observation, interview and documentation techniques. Next, the result was analyzed by using qualitative method with data triangulation analysis technique. In addition, the result of research showed that to build the attitude of nationalism to the students joining hizbul wathan could be done through various activities that fostered patriotism and good social relation in society. Hizbul wathan activities at SMA Muhammadiyah 1 Palembang were conducted through routine activities held in schools. The activities included holding a flag ceremony which was followed by all students to foster the character and attitude of loving their homeland, going camping to make the students get accustomed to be discipline, independence and care each other's and also using Indonesian language during hizbul wathan activities and other activities. This study also found that there were some problems faced by the school in the fostering process; they were the lack of hizbul wathan instructor and coach, the facilities and infrastructure especially an inadequate field to support the activities, and also the lack of focus which came from some students who joined another extracurricular beside hizbul wathan.
\end{abstract}

Keywords-attitude of nationalism; characters; extracurricular; fostering

\section{INTRODUCTION}

Hizbul Wathan is one form of extracurricular activities that develop in Islamic schools. Muhammadiyah is a school that has a strong Islamic base in Indonesia. At the elementary school level until the muhammadiyah education college develops activities that can develop the character and attitude of student nationalism through Hizbul wathan activities that are followed by every young citizen. SMA Muhammadiyah 1 Palembang is one of Islamic-based formal education institutions, which organizes extracurricular activities in the form of guiding the attitude of nationalism that prioritizes religiosity. Extracurricular activities are one of them is extracurricular activities Hizbul Wathan. This activity is a mandatory activity to be followed by students and students in the school environment muhammadiyah. Hizbul Wathan (from Arabic meaning homeland defender), is a system of education outside the family and school for children, youth and youth done in the open with an interesting method, fun and challenging, in order to form a useful and independent citizen so as to create a devoted human being by sticking to religious norms especially in an era that has been globalized like today [1].

Rapid globalization is a major cause of the deterioration of nationalism. The decrease in the spirit and attitude of nationalism among youth today has been increasing. According to opinion polls quoted from mass media (Kompas) last year 2014, that public recording in assessing student behavior is currently not sufficient in a number of areas [2]. For example, in the commemoration of national holidays such as the youth oath is only interpreted as ceremonial and entertainment without raising a sense of nationalism in their minds, then in the affairs of pancasila practice as a state ideology of about 73.6 percent of respondents see the students do not take part, in realizing the precepts in Pancasila. Then as additional respondents from 100 percent calculations only about 9.4 percent can mention correctly and sequentially the three contents "Youth Pledge".

From the above explanation can be concluded that the youth of Indonesia is now experiencing a decline in the sense of nationalism so that such a situation can adversely affect the resilience of the Indonesian nation. For that we need an understanding of nationalism and character building that can be applied in schools through nationalistic behavior to keep the Indonesian nation is not easy to experience the split especially among youth today.

According to Mahoney in Somantri the definition of civic education is to include all school activities including extracurricular activities in the framework of civic education; activities in and out of class (student government). In short, all school activities are the responsibility of schools to be incorporated into civic education [3]. It means that extracurricular activities belong to the domain of civic education. The expected objectives of this research are as follows: 
- Knowing the forms of nationalism building guidance programs through Hizbul Wathan activities so as to build student character.

- Knowing the results of coaching through extracurricular activities Hizbul Wathan in order to improve student nationalism attitude

- Knowing the obstacles faced in extracurricular activities Hizbul Wathan in order to improve the attitude of student nationalism to build the character of students.

- Know the solution to overcome the obstacles faced in the extracurricular exercise of Hizbul Wathan in order to improve the student's nationalism attitude.

\section{THEORETICAL REVIEW}

\section{A. The establishment of Nationalism}

Growing the spirit of nationalism is not an easy problem because nationalism must be from the idealism attached to a person. As long as the person does not have idealism as a nation united in the reality of diversity, then the awareness of nationalism still needs to be established. But the process of establishing awareness of nationalism must go through certain phases as follows:

Nationalism at the stage of its formation, as in times of national movement, is more attached to subjective elements, such as group consciousness, we-sentiment, corporate will, and various other mental facts [4].

So the awareness of nationalism at the beginning of its formation is based on group consciousness, sentiment (feeling) and group wills expressed in various forms of action. Nationalism at this stage by Kartodirdjo, is called the "sociopsychological fact" [4]. Furthermore, the most essential elements in the development of group consciousness of nationalism are the elements of mutual aspiration together in achieving common goals, as a nation. So nationalism at the beginning of its formation must be built from a collective consciousness based on strong nationalist ideals of individuals and groups, which dynamically synergize, and in turn produce a great national force of "persatuan dan kesatuan".

\section{B. Understanding Extracurricular Activities}

Extracurricular activities as one of the path of student coaching and supporting learning activities. Zainal and Sujak 2011 stated that extracurricular activities are activities that are outside the learning and teaching activities [5]. This activity is required to support curricular activities. All students are required to attend this event even though only one activity.

\section{Hizbul Wathan}

Hizbul Wathan is a typical Islamic scouting movement that encourages and accommodates the spirit of youth to be disciplined in discipline, skill, intelligence and shaping the akhlaqul karimah spirit that is oriented towards the three principles of "Educative, recreate, and religion".

According to Dzikron, Hizbul wathan is an autonomous organization muhammadiyah engaged in scouting to prepare and foster children, adolescents, and youth who have aqidah, mental, and physical knowledge and technology and morals karimah with the aim for the realization of personal muslim truthfully and ready to become a cadre of unions, people and nations with challenging and fun methods [6].

\section{Characters}

Characters have diverse insights according to the point of view used. The first character according to $\mathrm{Ki}$ Hadjar Dewantara is character or character [7]. Character as a unity of thoughts, feelings, and will which then generate power to act. Second, character is the nature of a person in responding to the situation morally. There are three parts of the interconnected behavior of a person possessing moral knowing, then arousing the will to the good of moral feeling so as to do good in the form of moral behavior [8], [9].

A good character or good character consists of three psychological processes of knowing the good [8], [9]. The substance of these three psychological processes begins leading to the moral life and moral maturity of the individual. Thus a person of character is a person who has integrity so that his thoughts, feelings, and will and behavior are true and consistent. Besides that, a good character can start with a good thought and good will to give birth to good action. However, the process of development and character formation in a person is influenced by two factors, namely environmental factors and innate factors [9]

\section{RESEARCH METHODS}

The research design used in this study used a qualitative approach. According to Cresswell, qualitative research is a process of research based on different methodological traditions, that is, by investigating social or humanitarian problems [10]. In qualitative research a researcher should be able to create complex images, an overall picture, analyze words, report in detail about the views or opinions of informants, and conduct research naturally. This research will discuss about the form of coaching the attitude of nationalism through the extracurricular activities of hizbul wathan to build the character of the students. The method used is case study.

Determination of participants in this study was conducted by purposive. According to Nasution, the determination of research subjects by purposive is done by taking the people who are selected by the researcher based on the specific characteristics they have, for example people with a certain level of education, have a certain age, who have been active in the activity certain [11]. Data collection through interview techniques, observavsi, and documentation. Data analysis includes data reduction, data presentation and conclusion drawing. The technique of testing the validity of the data using source triangulation.

\section{RESUlt AND DisCUSSION}

The cultivation of the attitude of religious nationalism is known to be instilled through the pattern of habituation such as inviting students to buy and use domestic products as an effort to enhance students' sense of pride to their country, so that after students have a sense of pride to the country then the attitude of nationalism can be embedded and grow in students. The attitude of nationalism can also be instilled through the pattern 
of habituation by teaching students to always use good and proper Indonesian language in school environment or in extracurricular activities of Hizbul Wathan without leaving the local language which is the richness of Indonesian culture. It aims to increase the love of students to their homeland, so that the attitude of nationalism can be embedded in students. This is supported by the results of Nodia's research. G, entitled "Nationalism and Democracy," explains that nationalism is a nationalism in which one does not regard tribe, race, and culture to create a democratic political life in the country.

Students' religious attitudes can be instilled through activities and patterns of habituation done by the school such as conducting worship on time between training sessions and extracurricular camp Hizbul Wathan, being patient, honest and just to others in the school environment and daily life, defending truth and preventing munkar are known to implant religious attitudes on students. Through extracurricular activities Hizbul Wathan proved to inculcate the attitude of religious nationalism of students in SMA Muhammadiyah 1 Palembang. This is supported by the results of research Jonathan H.W, entitled "Religion, Ethnicity and Cooperation: An Experimental Study", explains that religion and the religiosity of each individual can affect one's cooperation and sensitivity. Therefore, schools wishing to instill religious nationalism to students can make Hizbul Wathan's extracurricular activities as a means of planting religious nationalist attitudes, because they are perceived as more precise and effective.

\section{CONCLUSION}

The results of this study are the forms of religious religious nationalism through the extracurricular activities of Hizbul Wathan in SMA Muhammadiyah 1 Palembang, that is through the process of learning both material and practice in extracurricular activities Hizbul Wathan and patterns of habituation to students conducted by mentor and assisted by the school is known attitude of religious nationalism can be embedded in students.

\section{REFERENCES}

[1] P. Kusumandari, Menajemen Ekstrakurikuler Hizbul Wathan Untuk Membentuk Karakter Kepemimpinan Siswa Kelas X SMA Muhammadiyah 2 Yogyakarta, (Skripsi, Yogyakarta, Universitas Islam Negeri Sunan Kalijaga Yogyakarta), 2015.

[2] Kompas, 2014.

[3] N. Somantri, Menggagas Pembaruan Baru Pendidikan IPS, Bandung: Rosdakarya, 2001.

[4] S. Kartodirdjo, Pendekatan Ilmu Sosial dalam Metodologi Sejarah, Jakarta: Gramedia Pustaka Utama, 1993.

[5] Zainal dan Sujak, Panduan dan Aplikasi Pendidikan Karakter, Bandung: Yrama Widya, 2011.

[6] Dzikron, Panduan Gerakan Hizbul Wathan di Sekolah, Yogyakarta: Rekatima Media, 2011.

[7] K.H. Dewantara, Pemikiran, Konsepsi, Keteladanan, Sikap Merdeka, ed 2, kebudayaan, 2013,

[8] T. Lickona, Character Matters Persoalan Karakter Bagaimana Membantu Anak Mengembangkan Penilaian yang Baik, Integritas, dan kebajikan Penting Lainnya, Diterjemahkan oleh Juma Abdu Waaungo dan jean Antunes Rudolf Zien, Jakarta : Bumi Aksara, 2015.

[9] A. Wibowo, Menajemen Pendidikan Karakter di Sekolah (Konsep dan Praktik Impelementasi), Yogyakarta: Pusataka Pelajar, 2016.

[10] J.W. Cresswell, Educational Research (Planning, Conducting, and Evaluating Quantitative and Qualitative Research), California: Pearson Sage Publications, 2015.

[11] Nasution, Metode Research (Penelitian Ilmiah), Jakarta: PT Bumi Aksara, 2009 